JURNAL RISET PENDIDIKAN MATEMATIKA

Volume 3 - Nomor 1, Mei 2016, (23 - 33)

Available online at http://journal.uny.ac.id/index.php/jrpm

\title{
PENGEMBANGAN PERANGKAT PEMBELAJARAN STATISTIKA DAN PELUANG DENGAN METODE PENEMUAN TERBIMBING BERORIENTASI KURIKULUM 2013 UNTUK SISWA KELAS $X$
}

\author{
Dian Wijayanti \\ SD Negeri Maospati 3. Jalan Raya Maospati, Kabupaten Magetan, Indonesia \\ Korespondensi Penulis. Email: d.vijayanti@gmail.com, Telp: +6285815840989 \\ Received: $28^{\text {th }}$ October 2015; Revised: $30^{\text {th }}$ June 2016; Accepted: $6^{\text {th }}$ September 2016
}

\begin{abstract}
Abstrak
Tujuan penelitian ini adalah menghasilkan perangkat pembelajaran statistika dan peluang untuk siswa SMA kelas X semester 2 dengan metode penemuan terbimbing yang terdiri atas RPP, LKS, dan instrumen penilaian yang memenuhi kriteria valid, praktis, dan efektif. Model pengembangan dalam penelitian ini adalah model 4D, terdiri atas tahap pendefinisian, perancangan, pengembangan, dan penyebaran. Analisis data kevalidan dan kepraktisan dilakukan dengan cara mengkonversi data kuantitatif berupa skor hasil penilaian menjadi data kualitatif skala lima. Analisis data keefektifan dilakukan dengan cara menentukan persentase ketuntasan belajar siswa berdasarkan hasil tes dan angket. Hasil validasi menunjukkan bahwa RPP yang dikembangkan memperoleh kategori baik, sedangkan LKS dan instrumen penilaian yang dikembangkan mencapai kategori sangat baik. Hasil observasi keterlaksanaan pembelajaran menunjukkan bahwa keterlaksanaan pembelajaran statisika mencapai $94,12 \%$ sedangkan peluang mencapai $84,29 \%$. Berdasarkan hasil tes dan angket, perangkat pembelajaran termasuk dalam kriteria efektif.
\end{abstract}

Kata Kunci: perangkat pembelajaran, penemuan terbimbing, statistika, peluang.

\section{DEVELOPING STATISTICS AND PROBABILITY TEACHING KIT WITH GUIDED DISCOVERY LEARNING METHOD ORIENTED TO CURRICULUM 2013 FOR GRADE X}

\begin{abstract}
This research aimed to produce statistics and probability teaching kit for grade $X$ students of Senior High School in 2nd semester with guided discovery learning consist of lesson plans, student worksheets, and assessment instruments which valid, practical, and effective. The developing model in this research was $4 D$ model consist of define, design, develop, and disseminate. Validity and practicality were analyzed by converting the actual scores obtained into five scales of qualitative data. Effectiveness analyzed by determining the percentage of students' completeness in a test and in the questionnaires. Validation result shows that the lesson plans have good category, the student worksheet and the assessment instrument have very good categories. The result of the application shows that the statistics application was 94,12\% than the probability application was 84,29\%. Based on the test and questionnaires result, the teaching kit was in effective term.
\end{abstract}

Keywords: teaching kit, guided discovery, statistics, probability

How to Cite: Wijayanti, D. (2016). Pengembangan perangkat pembelajaran statistika dan peluang dengan metode penemuan terbimbing berorientasi kurikulum 2013 untuk siswa kelas X. Jurnal Riset Pendidikan Matematika, 3(1), 23-33. doi:http://dx.doi.org/10.21831/jrpm.v3i1.6449

Permalink/ DOI: http://dx.doi.org/10.21831/jrpm.v3i1.6449 


\section{Jurnal Riset Pendidikan Matematika, 3 (1), Mei 2016 - 24}

Dian Wijayanti

\section{PENDAHULUAN}

Kurikulum 2013 bertujuan untuk mempersiapkan manusia Indonesia agar memiliki kemampuan hidup sebagai pribadi dan warga negara yang beriman, produktif, kreatif, inovatif, dan afektif serta mampu berkontribusi pada kehidupan bermasyarakat, berbangsa, bernegara, dan peradaban dunia. Kurikulum 2013 merupakan kurikulum yang berbasis kompetensi dan berbasis karakter. Penilaian ketuntasan belajar siswa tidak hanya dilihat dari kemampuan kognitif siswa tetapi juga dilihat dari sikap siswa. Dalam Kurikulum 2013 terdapat beberapa perubahan yang mencakup Standar Proses, Standar Kompetensi, Standar Isi, dan Standar Penilaian.

Proses pembelajaran dalam Kurikulum 2013 menekankan pada prinsip pembelajaran siswa aktif. Hal ini sesuai dengan prinsip belajar konstruktivisme dimana menurut pandangan konstruktivisme, belajar adalah pencarian makna (Muijs \& Reynolds, 2008, p.98). Belajar diartikan sebagai proses aktif dimana pembelajar mengkonstruksi hubungan yang bermakna antara pengetahuan baru yang diberikan dalam pembelajaran dengan pengetahuan yang ada pada pembelajar (Kemp, Morrison \& Ross, 1994, p.120). Metode-metode pembelajaran dalam Kurikulum 2013 antara lain project based learning, problem based learning, discovery/inquiry, dan pendekatan saintifik. Namun demikian metode-metode pembelajaran yang disarankan dalam Kurikulum 2013 masih jarang digunakan, tidak terkecuali metode pembelajaran penemuan (discovery). Hal ini dikarenakan guru masih lebih nyaman menggunakan pembelajaran ekspositori.

Pembelajaran dengan metode penemuan (discovery) terjadi sebagai hasil dari siswa memanipulasi, menyusun dan mentransformasi informasi sehingga mereka menemukan informasi baru (Bell, 1981, p.241). Alfieri, et al (2011, p.2) menyatakan bahwa pembelajaran penemuan terjadi ketika siswa tidak disedikan target informasi atau pemahaman konsep dan harus menemukan sendiri dengan bahah-bahan yang tersedia. Moore (2009, p.178) menyatakan bahwa dalam pembelajaran penemuan siswa terlibat dalam pemecahan masalah dalam mengembangkan pengetahuan atau keterampilan. Dalam pembelajaran penemuan siswa juga dapat membuat suatu hubungan dan melihat keterkaitannya tanpa harus dijelaskan oleh guru (Orton, 2006, p.77). Dengan demikian pembelajaran dengan metode penemuan memungkinkan siswa untuk berpartisipasi lebih aktif dalam pembelajaran dengan mencoba menemukan sendiri suatu konsep dan tidak hanya menunggu diberitahu oleh guru.

Namun demikian menurut Kirschner, Sweller, \& Clark (2006, p.84) pembelajaran tidak terbimbing normalnya kurang efektif, disamping itu pembelajaran tidak terbimbing mungkin akan memperoleh hasil negatif ketika siswa mendapatkan konsep yang keliru atau pengetahuan yang tidak lengkap atau tidak terorganisir. Oleh karena itu, dalam pembelajaran penemuan masih diperlukan arahan dari guru dimana guru menyusun kegiatan yang melibatkan siswa untuk mencari, memanipulasi, mengeksplorasi, dan menginvestigasi (Schunk, 2008,p.280). Hal ini diperkuat oleh Tran, et al (2014, p.51) yang menyatakan bahwa dalam pembelajaran penemuan terbimbing guru memberikan masalah, menyediakan bahan-bahan atau alat-alat dan lingkungan yang diperlukan agar siswa mendapat kesempatan untuk menemukan atau memecahkan masalah. Guru disini berperan untuk membantu dan memastikan siswa tidak mendapat masalah dalam menyelesaikan masalah yang diberikan.

Hasil penelitian Mayer (2004, p.14) menunjukkan bahwa penemuan terbimbing lebih efektif dibandingkan penemuan murni untuk membantu siswa belajar. Sementara dari hasil penelitian Yuliawati (2010, pp.144-145) menunjukkan bahwa penerapan pendekatan penemuan terbimbing pada pembelajaran sains dapat meningkatkan karakter dan hasil belajar sains siswa kelas 5 SD Negeri Gembongan, Sentolo, Kulon Progo. Penelitian lain yang dilakukan oleh Akanmu \& Fajemidagba (2013, p.85) menunjukkan bahwa terdapat perbedaan yang signifikan dalam prestasi belajar matematika siswa yang diajar menggunakan strategi pembelajaran penemuan terbimbing dibandingkan dengan siswa yang diajar dengan menggunakan strategi pembelajaran yang lain. Hasil penelitian tersebut juga menunjukkan bahwa dengan strategi pembelajaran penemuan terbimbing terjadi peningkatan prestasi belajar siswa. Di samping itu, penelitian ini juga menemukan bahwa perbedaan gender tidak memiliki peran dalam prestasi belajar matematika siswa. Selain itu, hasil penelitian Afandi (2013) juga menunjukkan bahwa penemuan terbimbing dalam pembelajaran matematika efektif ditinjau dari kemampuan pemecahan masalah dan representasi multipel matamatis siswa.

Sementara itu perubahan dalam rekonstruksi kompetensi mencakup kompetensi sikap 


\section{Jurnal Riset Pendidikan Matematika, 3 (1), Mei 2016 - 25}

Dian Wijayanti

yang meliputi sikap spiritual dan sikap sosial, kompetensi pengetahuan dan kompetensi keterampilan. Penanaman nilai-nilai moral sangat penting dilakukan mengingat perkembangan ilmu pengetahuan dan teknologi yang semakin pesat dan tak jarang menimbulkan pengaruh yang negatif terhadap generasi muda. Penanaman nilai-nilai agama, sosial, dan moral tidak hanya dilaksanakan pada mata pelajaran pendidikan kewarganegaraan atau pendidikan agama tetapi juga dapat diintegrasikan pada setiap mata pelajaran, sebagaimana dikemukan oleh Mulyasa (2014, p.7) bahwa materi pembelajaran yang berkaitan dengan norma atau nilai-nilai pada setiap bidang studi perlu dikembangkan, dieksplisitkan, dihubungkan dengan konteks kehidupan sehari-hari.

Sikap spritual pada dasarnya terkait dengan religiusitas. Religiusitas berkenaan dengan pernyataan tentang kepercayaan seseorang terhadap Tuhan, ditandai oleh kesalehan dan semangat religi (Salleh, 2012, p.266). Tilouine \& Belgoumidi (2009, p.115) membagi religiusitas dalam empat domain yaitu Religious Belief, Practice, Altruism, dan Enrichment. Domain pertama yaitu Religious Belief berhubungan dengan masalah keimanan seperti percaya kepada Tuhan, hari akhir, surga, neraka, dan kitab suci. Domain Religious Practice berhubungan dengan masalah praktik seperti shalat, puasa, tidak meminum-minuman keras, dan cara berpakaian. Domain Religious Altruism berhubungan dengan aspek interaksi antara sesama manusia seperti berbakti pada orang tua, kekerabatan, hidup bertetangga dan saling menasihati antar sesama. Domain terakhir yaitu Religious Enrichment berhubungan dengan aktifitas memperluas pengetahuan dan pengalaman spiritual seperti membaca buku-buku keagamaan, mengahadiri pengajian, dan membaca Al Qur'an. Menurut Glock \& Stark (Holdcroft, 2006, p.89) ada lima dimensi dalam religiusitas yaitu experiential (pengalaman), ritualistic (ritual), ideological (ideologi), intellectual (intelektual), and consequential (sebab-akibat). Verbit (Salleh, 2012, p.267) membagi religiusitas dalam enam komponen yaitu ritual (ritual), doctrine (doktrin), emotion (emosi), knowlegde (pengetahuan), ethics (etika), and community (masyarakat). Dengan demikian secara umum ada dua aspek dalam religiusitas yaitu hubungan manusia dengan Tuhan dan hubungan manusia dengan sesama manusia.

Kompetensi dasar sikap spiritual dalam Kurikulum 2013 adalah menghayati dan meng- amalkan ajaran agama yang dianutnya. Dengan demikian sikap spiritual terkait dengan pembentukan siswa yang beriman dan bertakwa. Wagner (Hurlock, 1996, p.222) menyatakan banyak remaja menyelidiki agama sebagai suatu sumber dari rangsangan emosional dan intelektual, mereka ingin mempelajari agama berdasarkan pengertian intelektual dan tidak ingin menerimanya begitu saja. Berdasarkan hasil penelitian secara kritis terhadap keyakinan masa kanak-kanak, remaja sering bersikap skeptis terhadap berbagai bentuk religius dan kemudian mulai meragukan isi religius. Bagi beberapa remaja keraguan ini dapat membuat mereka kurang taat pada agama, sedangkan remaja yang lain berusaha untuk mencari kepercayaan lain yang dapat memenuhi kebutuhan dari pada kepercayaan yang dianut keluarganya (Hurlock, 1996, p.223). Oleh sebab itu, penanaman sikap spiritual atau religiusitas sangat penting ditanamkan sehingga siswa-siswa tersebut memiliki pemahaman yang utuh tentang kepercayaan yang dianutnya dan tidak hanya mengikuti arus.

Sikap sosial terkait dengan pembentukan siswa yang berakhlak mulia, mandiri, demokratis dan bertanggungjawab. Hurlock (1996, p.213) menyatakan bahwa salah satu tugas perkembangan masa remaja yang tersulit adalah yang berhubungan dengan penyesuaian sosial. Siswa SMA telah mencapai tahap operasional formal dalam kemampuan kognitif. Pada masa ini terjadi perubahan konsep moral dari konsep moral khusus ke dalam konsep yang berlaku umum tentang benar dan salah (Hurlock, 1996, p.225). Oleh karena itu, pendidikan moral penting untuk ditanamkan, tidak hanya memberikan doktrin tentang apa yang benar dan apa yang salah tetapi juga memberikan alasan kenapa hal tersebut benar atau salah. Nilai-nilai sosial yang dapat diintegrasikan dalam mata pelajaran matematika antara lain disiplin, tanggung jawab dan jujur. Dalam hal ini perhatian orang tua, guru, dan lingkungan sangat penting bagi perkembangan siswa. Hasil penelitian Kurniawan \& Wutsqa (2014, p.176) menyatakan bahwa peran orang tua, motivasi belajar, dan lingkungan sosial secara bersama-sama memberikan pengaruh yang signifikan terhadap prestasi belajar siswa SMP.

Kedisiplinan merupakan hal yang penting dalam pembelajaran di kelas. Tanpa adanya disiplin dalam kelas, pembelajaran akan cenderung kacau dan tidak efektif. Boynton (2005, p.3) menyatakan ada empat komponen penting dalam membangun sistem disiplin kelas yang 
efektif yaitu hubungan yang positif antara guru dengan siswa, parameter yang jelas perilaku siswa yang dapat diterima, keterampilan memonitor, dan konsekuensi. Ada dua kategori dalam membangun kedisiplinan yaitu pencegahan dan perbaikan (Lickona, 2004, p.145). Strategi pencegahan yang baik akan mengurangi frekuensi masalah perilaku disiplin siswa, akan tetapi jika masalah tetap timbul strategi perbaikan akan diperlukan untuk mengatasinya. Oleh karena itu, upaya menanamkan sikap disiplin dilakukan dalam setiap pembelajaran untuk mengurangi frekuensi masalah perilaku disiplin siswa.

Selain disiplin, sikap sosial lainnya yang perlu ditanamkan dalam pembelajaran matematika yaitu tanggung jawab. Tanggung jawab merupakan salah satu sikap yang harus dimiliki oleh seseorang. Siswa sekolah menengah atas berada pada masa akhir remaja, oleh karenanya sikap tanggung jawab sangatlah penting bagi mereka karena pada masa ini remaja harus membuat banyak penyesuaian baru yang sesuai dengan pola sosialisasi dewasa. Tanggung jawab berarti kemampuan untuk merespon, yaitu merespon orang lain, memperhatikan orang lain, merespon secara aktif keinginan atau kebutuhan orang lain (Lickona, 1991, p.44). Orang yang bertanggung jawab bertindak tidak hanya untuk kepentingan diri sendiri tetapi juga memperhatikan hak-hak orang lain. Tanggung jawab berarti menyelesaikan pekerjaan atau tugas baik dalam keluarga, sekolah ataupun di tempat kerja sesuai dengan kemampuan terbaik yang dimiliki (Lickona, 1991, p.44). Dengan demikian seseorang dapat dikatakan bertanggungjawab bila menyelesaikan tugas dengan baik dengan memperhatikan kepentingan dan kebutuhan orang lain serta sanggup menanggung segala akibat dari tindakannya.

Sikap sosial yang tak kalah penting untuk ditanamkan sejak dini bagi generasi muda adalah kejujuran. Koellhoffer (2009, p.27) menyatakan jujur berarti mengatakan kebenaran, berperilaku terhormat dan tidak berbohong, menipu, curang, berkhianat atau mencuri. Melihat banyaknya kasus korupsi yang terjadi di Indonesia, kejujuran merupakan hal yang harus ditanamkan sejak dini bagi generasi muda untuk menciptakan masa depan yang lebih baik. Namun demikian untuk menjadi jujur terhadap orang lain seseorang harus jujur terhadap dirinya terlebih dahulu. Permasalahan dalam kejujuran pada diri sendiri adalah kemampuan untuk menghadapi kenyataan, keyakinan dan perasaan secara terbuka (Menlove, 2012, p.45). Baik jujur terhadap diri sendiri maupun jujur terhadap orang lain bukanlah hal yang mudah untuk dilakukan, terutama bila lingkungan tidak mendukung. Kejujuran akademik merupakan hal harus diperhatikan sebab jika potensi untuk tidak jujur siswa tinggi maka kemungkinan untuk tidak jujur saat mereka bekerja juga tinggi (Tamayo, 2014, p.1).

Kompetensi inti ketiga yang harus dicapai oleh siswa dalam pembelajaran adalah kompetensi pengetahuan. Kompetensi pengetahuan merupakan kompetensi ranah kognitif dalam taksonomi pendidikan. Menurut Permendikbud Nomor 59 Tahun 2014, pengetahuan adalah informasi yang diketahui atau dipahami oleh seseorang yang dapat berupa deskripsi, hipotesis, konsep, teori, prinsip dan prosedur yang diyakini benar atau berguna. Anderson \& Krathwohl (2001, p.27) membagi pengetahuan menjadi empat tipe yaitu pengetahuan faktual, konseptual, prosedural, dan metakognitif. Pengetahuan faktual terdiri atas pengetahuan tentang istilah (terminology) dan pengetahuan tentang detail-detail dan elemen-elemen tertentu. Pengetahuan konseptual meliputi pengetahuan tentang klasifikasi dan kategori, prinsip dan generalisasi serta pengetahuan tentang teori, model, dan struktur. Pengetahuan prosedural adalah pengetahuan bagaimana melakukan sesuatu, metode-metode penemuan, dan kriteria penggunaan keterampilan, algoritma, teknik, dan metode. Pengetahuan metakognitif meliputi pengetahuan strategi, pengetahuan tentang tugas-tugas kognitif, dan pengetahuan diri (Anderson \& Krathwohl, 2001, p.29).

Kompetensi keterampilan merupakan kompetensi inti keempat yang harus dikuasai oleh siswa. Permendikbud Nomor 59 Tahun 2014 menyatakan bahwa keterampilan, kemahiran, kecakapan atau keahlian (skill) dalam melaksanakan tugas merupakan kemampuan untuk menggunakan akal, pikiran, ide, dan kreativitas dalam mengerjakan, mengubah ataupun membuat sesuatu menjadi lebih bermakna sehingga menghasilkan sebuah nilai dari hasil pekerjaan tersebut. Menurut Gibb (Suydam \& Dessart, 1980, p.208), terdapat empat basic skill (keterampilan dasar) dalam matematika yaitu pemahaman terhadap konsep matematika dan teknik perhitungan, keterampilan dalam menggunakan pemahaman yang dimiliki dalam perhitungan, keterampilan dalam pemecahan masalah, serta keterampilan dalam hal berpikir kreatif. 
Hasil penelitian Rumasoreng \& Sugiman (2014, p.22) menyebutkan bahwa urutan tingkat kesulitan siswa dalam menyelesaikan soal setara UN terjadi dalam hal kesulitan keterampilan, konsep, dan prinsip. Sedangkan faktor-faktor yang menyebabkan kesulitan siswa adalah siswa tidak mampu dalam hal penguasaan konsep, perpaduan antarkonsep, keterampilan dalam menyelesaikan soal turunan dalam trigonometri dan teknik integral, penggunaan perbandingan trigonometri, penentuan banyaknya pilihan dalam menyelesaikan soal kombinasi, penentuan persamaan garis singgung lingkaran, penggunaan aturan kosinus dalam menentukan volume bangun ruang, penggunaan konsep limit baik bentuk aljabar maupun trigonometri, pembuatan model matematika, dan penentuan daerah asal suatu fungsi komposisi.

Penerapan Kurikulum 2013 tergolong baru oleh karenanya ketersediaan perangkat pembelajaran yang memberikan kemudahan bagi guru untuk menerapkan Kurikulum 2013 masih terbatas,tidak terkecuali perangkat pembelajaran matematika. Matematika merupakan salah satu materi yang wajib dipelajari di sekolah. Siswa di sekolah menengah atas menghadapi banyak pilihan dan keputusan yang akan menentukan jalan hidup mereka. untuk memastikan siswa-siswa mendapatkan pilihan karir dan pendidikan yang luas oleh karenanya pembelajaran matematika di sekolah menengah haruslah luas dan mendalam (NCTM, 2000, p.287).

Penelitian ini bertujuan untuk menghasilkan dan menguji kualitas perangkat pembelajaran dengan metode penemuan terbimbing yang berorientasi pada pencapaian kompetensi inti Kurikulum 2013 untuk siswa sekolah menengah atas. Perangkat pembelajaran yang dikembangkan terdiri atas Rencana Pelaksanaan Pembelajaran (RPP), Lembar Kegiatan Siswa (LKS), dan instrumen penilaian berupa tes dan angket.

Bagi guru RPP merupakan hal penting dalam pembelajaran. RPP yang baik dapat membantu terlaksananya pembelajaran yang efektif. Program belajar yang berhasil memerlukan kesesuaian antara apa yang dipelajari dengan kualitas pelajar (Stringer, 2010, p.4). RPP yang dikembangkan pada penelitian ini sesuai dengan Kurikulum 2013. Pada penelitian ini LKS yang dirancang agar siswa dapat menemukan fakta, konsep, prinsip, maupun prosedur matematis dari materi yang dipelajari. Hasil penelitian Syawahid \& Retnawati (2014, p.19) menyatakan bahwa penggunaan perangkat pembelajaran terintegrasi dengan pengembangan kecerdasan emosional dan spiritual lebih efektif dari penggunaan perangkat pembelajaran yang tersedia di sekolah ditinjau dari hasil belajar siswa, di samping itu penggunaan perangkat pembelajaran terintegrasi dengan pengembangan kecerdasan emosional dan spiritual lebih efektif dari penggunaan perangkat pembelajaran yang tersedia di sekolah ditinjau dari kecerdasan emosional dan spiritual siswa.

\section{METODE}

\section{Jenis Penelitian}

Penelitian ini merupakan penelitian pengembangan. Model pengembangan yang digunakan adalah model 4D (Thiagarajan, Semmel, \& Semmel, 1974, pp.6-9) dengan empat tahap pengembangan yaitu pendefinisian (define), perancangan (design), pengembangan (develop), dan penyebarluasan (disseminate). Produk dari penelitian pengembangan ini berupa perangkat pembelajaran statistika dan peluang dengan metode penemuan terbimbing berdasarkan Kurikulum 2013 untuk siswa kelas X semester 2.

\section{Prosedur}

Kegiatan-kegiatan yang dilakukan dalam mengembangkan perangkat pembelajaran ini dimulai dengan tahap pendefinisian. Dalam tahap pendefinisian dilakukan analisis awal akhir, analisis siswa, analisis konsep, analisis tugas, dan spesifikasi tujuan pembelajaran. Tahap kedua dalam pengembangan ini adalah perancangan. Pada fase ini dilakukan kegiatan merancang dan menyusun RPP serta merancang dan menyusun LKS, dan instrumen penilaian berupa angket dan tes hasil belajar. Hasil dari fase ini adalah draft 1 .

\section{Subjek Uji coba, Waktu dan Tempat Penelitian}

Uji coba dalam penelitian ini meliputi uji keterbacaan dan uji coba lapangan. Uji keterbacaan dilaksanakan pada hari Sabtu tanggal 18 April 2015 yang bertujuan untuk memperoleh tanggapan dari siswa sebagai bahan pertimbangan untuk memperbaiki LKS sebelum diimplementasikan pada pembelajaran di kelas. Subjek penelitian pada uji keterbacaan adalah 18 siswa kelas XI dengan kemampuan rendah, sedang, dan tinggi. Subjek uji coba lapangan adalah siswa kelas X MIA 5 dan X MIA 6. Kelas X MIA 5 digunakan untuk uji coba materi statistika, sedangkan kelas X MIA 6 digunakan untuk uji 
coba materi peluang. Implementasi pembelajaran matematika menggunakan perangkat pembelajaran yang dikembangkan dilaksanakan sebanyak lima kali pertemuan untuk masing-masing kelas dengan rincian satu kali pertemuan untuk pretest, tiga kali pertemuan untuk pembelajaran, dan satu kali pertemuan untuk posttest. Untuk kelas X MIA 5 pelaksanaan uji coba lapangan dilaksanakan mulai hari Senin tanggal 20 April 2015 dan berakhir pada hari Senin tanggal 11 Mei 2015, sedangkan untuk kelas X MIA 6 pelaksanaan uji coba lapangan dimulai hari Senin tanggal 20 April 2015 dan berakhir pada hari Jum'at tanggal 15 Mei 2015.

\section{Data, Instrumen, dan Teknik Pengumpulan Data}

Data dalam penelitian ini berupa data validasi ahli, data penilaian guru, data observasi keterlaksanaan proses pembelajaran, data penilaian siswa, data tes hasil belajar, data angket penilaian diri. Instrumen penelitian yang digunakan meliputi (1) lembar validasi untuk mengukur kevalidan, (2) lembar penilaian guru, lembar penilaian siswa, dan lembar observasi keterlaksanaan pembelajaran untuk mengukur kepraktisan, (3) tes hasil belajar dan angket penilaian diri untuk mengukur keefektifan.

Teknik pengumpulan data dalam penelitian ini dilakukan melalui pemberian lembar validasi, lembar penilaian guru, lembar penilaian siswa, tes hasil belajar, angket penilaian diri dan observasi kelas melalui lembar observasi keterlaksanaan proses pembelajaran.

\section{Teknik Analisis Data}

Teknik analisis data dalam penelitian ini dilakukan dengan mengkonversi data kuantitatif yang diperoleh menjadi data kualitatif skala lima dengan acuan rumus yang diadaptasi dari Azwar (2015, p.163) yang disajikan pada Tabel 1.

Tabel 1. Kriteria Konversi Data

\begin{tabular}{ccc}
\hline Rentang Skor & Nilai & Kategori \\
\hline$(\mathrm{M}+1,5 \mathrm{~s})<\mathrm{X}$ & A & Sangat Baik \\
$(\mathrm{M}+0,5 \mathrm{~s})<\mathrm{X} \leq(\mathrm{M}+1,5 \mathrm{~s})$ & B & Baik \\
$(\mathrm{M}-0,5 \mathrm{~s})<\mathrm{X} \leq(\mathrm{M}+0,5 \mathrm{~s})$ & $\mathrm{C}$ & Cukup Baik \\
$(\mathrm{M}-1,5 \mathrm{~s})<\mathrm{X} \leq(\mathrm{M}-0,5 \mathrm{~s})$ & $\mathrm{D}$ & Kurang Baik \\
$\mathrm{X} \leq(\mathrm{M}-1,5 \mathrm{~s})$ & $\mathrm{E}$ & Tidak Baik \\
\hline
\end{tabular}

Perangkat pembelajaran dikatakan valid jika hasil penilaian ahli mencapai kategori minimal baik, sedangkan untuk aspek kepraktisan dapat dilihat dari hasil penilaian guru, siswa dan hasil observasi keterlaksanaan pembelajaran. Perangkat pembelajaran dikatakan praktis jika hasil penilaian guru dan siswa mencapai kategori minimal baik. Dari hasil observasi keterlaksanaan pembelajaran, perangkat pembelajaran yang dikembangkan dikatakan praktis jika $80 \%$ pembelajaran dapat terlaksana. Untuk aspek keefektifan dilihat dari hasil tes dan angket. Perangkat pembelajaran dikatakan efektif jika berdasarkan hasil tes dan angket minimal $75 \%$ siswa telah tuntas kriteria ketuntasan minimal. Untuk tes hasil belajar dan angket, kriteria ketuntasan minimal sesuai dengan Permendikbud Nomor 104 Tahun 2014 yaitu 2,67 untuk kompetensi pengetahuan dan keterampilan serta predikat baik untuk kompetensi sikap.

\section{HASIL DAN PEMBAHASAN}

\section{Hasil Penelitian}

Hasil pengembangan produk awal berupa perangkat pembelajaran matematika dengan metode penemuan terbimbing menggunakan model pengembangan 4D diuraikan sebagai berikut.

\section{Tahap Pendefinisian}

Tahap pendefinisian meliputi tahap analisis awal-akhir, analisis siswa, analisis konsep, analisis tugas, dan spesifikasi tujuan pembelajaran. Pada tahap analisis awal-akhir dilakukan pengumpulan informasi-informasi yang penting tentang masalah dasar yang dihadapi. Informasi ini diperlukan dalam pengembangan perangkat pembelajaran yang dilakukan. Analisis siswa dilakukan dengan menelaah karakteristik siswa sekolah menengah atas. Pada tahap analisis konsep kegiatan yang dilakukan adalah menentukan materi pokok dan sikap-sikap yang akan dikembangkan dalam perangkat yang akan dibuat. Analisis tugas bertujuan untuk mengidentifikasi garis besar materi yang dipelajari dalam materi statistika dan peluang. Spesifikasi tujuan pembelajaran dilakukan untuk menentukan acuan atau target yang ingin dicapai dalam setiap pertemuan. Tujuan pembelajaran tidak hanya dalam kompetensi pengetahuan dan keterampilan saja tetapi juga tujuan dalam kompetensi sikap spiritual dan sosial.

\section{Tahap Perancangan}

Tahap perancangan bertujuan untuk mempersiapkan prototype perangkat pembelajaran. Langkah-langkah yang ditempuh pada tahap perancangan meliputi pemilihan media, format, dan perancangan awal. Pemilihan media berkaitan dengan penentuan media yang tepat untuk menyajikan materi pembelajaran. Format pembelajaran disesuaikan dengan metode pembel- 
ajaran yang digunakan yaitu metode pembelajaran penemuan terbimbing. Pada tahap perancangan awal disusun prototype perangkat pembelajaran yang berupa RPP, LKS, dan instrumen penilaian yang terdiri atas Tes Hasil Belajar (THB) dan angket penilaian diri. Hasil rancangan awal ini disebut draft 1 .

RPP dikembangkan dengan mengacu pada Permendikbud Nomor 103 Tahun 2014 tentang Pembelajaran pada Pendidikan Dasar dan Pendidikan Menengah. Komponen-komponen RPP meliputi (1) identitas sekolah/madrasah, mata pelajaran, dan kelas/semester; (2) alokasi waktu; (3) KI, KD, indikator pencapaian kompetensi; (4) materi pembelajaran; (5) kegiatan pembelajaran; (6) penilaian; dan (7) media/ alat, bahan, dan sumber belajar. RPP yang dikembangkan terdiri atas RPP statistika dan RPP peluang. Masing-masing RPP memuat rencana pembelajaran untuk tiga kali pertemuan.

LKS dikembangkan dengan mengikuti langkah-langkah pengembangan LKS yang ditetapkan oleh Depdiknas yang meliputi perumusan kompetensi dasar yang harus dikuasai, menentukan alat penilaian, penyusunan materi, dan struktur LKS. LKS yang dikembangkan pada draft 1 terdiri atas enam LKS masing-masing tiga LKS statistika dan tiga LKS peluang.

Instrumen penilaian yang dikembangkan terdiri atas THB dan angket penilaian diri. THB digunakan untuk mengukur pencapaian kompetensi pengetahuan dan keterampilan, sedangkan angket penilaian diri digunakan untuk mengukur pencapaian kompetensi sikap spiritual dan sikap sosial. Untuk kompetensi pengetahuan tes yang digunakan adalah tes pilihan ganda, sedangkan untuk kompetensi keterampilan tes yang digunakan adalah tes uraian. Untuk kompetensi sikap, aspek yang ingin diketahui adalah ketakwaan, disiplin, jujur dan tanggung jawab dengan instrumen penilaian berupa angket.

Tahap Pengembangan

Tahap pengembangan meliputi penilaian ahli, uji keterbacaan dan uji coba lapangan. Penilaian ahli merupakan kegiatan validasi perangkat pembelajaran sebelum diujicobakan. Validasi dilakukan dengan cara memberikan perangkat pembelajaran beserta lembar validasi kepada dua dosen Pendidikan Matematika Universitas Negeri Yogyakarta. Hasil penilaian ahli dapat dilihat pada Tabel 2.
Tabel 2. Hasil Validasi Ahli

\begin{tabular}{ccc}
\hline $\begin{array}{c}\text { Perangkat } \\
\text { Pembelajaran }\end{array}$ & $\begin{array}{c}\text { Skor Rata- } \\
\text { rata }\end{array}$ & Kriteria \\
\hline RPP & 112 & Valid \\
LKS & 83 & Valid \\
THB & 41 & Valid \\
Angket & 37,5 & Valid \\
\hline
\end{tabular}

Berdasarkan Tabel 2 diketahui bahwa masing-masing perangkat pembelajaran telah memenuhi kriteria valid, sehingga draft 1 telah layak untuk diujicobakan.

Uji keterbacaan merupakan uji coba terbatas yang melibatkan beberapa siswa kelas XI untuk melihat keterbacaan dari perangkat pembelajaran. Kelas XI dipilih untuk uji keterbacaan karena kelas XI pernah mempelajari materi yang dikembangkan. Hasil uji keterbacaan menyatakan bahwa LKS, THB dan angket yang dikembangkan masing-masing termasuk dalam kategori sangat baik, dengan demikian perangkat pembelajaran dapat digunakan untuk uji coba lapangan.

Uji coba lapangan dilaksanakan di dua kelas yaitu kelas X MIA 5 untuk uji coba materi statistika dan kelas X MIA 6 untuk uji coba materi peluang. Berdasarkan hasil observasi keterlaksanaan pembelajaran, persentase keterlaksanaan pembelajaran untuk materi peluang adalah $94,12 \%$ sedangkan persentase keterlaksanaan pembelajaran peluang adalah $84,29 \%$. Hasil penilaian guru menyatakan bahwa perangkat pembelajaran yang dikembangkan berada pada kategori baik dengan rincian yang disajikan pada Tabel 3.

Tabel 3. Hasil Penilaian Guru

\begin{tabular}{ccc}
\hline Komponen & Rata-rata & Kategori \\
\hline RPP & 18,5 & Baik \\
LKS & 20 & Baik \\
THB & 21,5 & Sangat baik \\
Angket & 20 & Baik \\
Jumlah & 80 & Baik \\
\hline
\end{tabular}

Berdasarkan hasil penilaian siswa diketahui bahwa LKS yang dikembangkan berada pada kategori sangat baik untuk materi statistika maupun peluang. Rincian hasil penilaian siswa pada uji coba lapangan dapat dilihat Tabel 4.

Tabel 4. Hasil Penilaian Siswa

\begin{tabular}{ccc}
\hline Materi & Skor Rata-rata & Kategori \\
\hline Statistika & 32,44 & Sangat Baik \\
Peluang & 33,84 & Sangat Baik \\
Rata-rata & 33,14 & Sangat Baik \\
\hline
\end{tabular}


Tabel 5 merupakan ringkasan hasil tes pilihan ganda yang diberikan kepada siswa setelah akhir pembelajaran.

Tabel 5. Hasil Tes Pilihan Ganda

\begin{tabular}{ccc}
\hline Tes & Statistika & Peluang \\
\hline Rata-rata & 3,61 & 3,34 \\
Persentase Ketuntasan & $100 \%$ & $93,55 \%$ \\
\hline
\end{tabular}

Berdasarkan Tabel 5 dapat diketahui bahwa rata-rata hasil tes pilihan ganda untuk statistika adalah 3,61 dan 3,34 untuk materi peluang. Nilai rata-rata ini lebih besar dari nilai kriteria ketuntasan minimal yaitu 2,67. Sementara itu persentase ketuntasan siswa baik untuk materi statistika maupun peluang lebih dari $75 \%$ untuk tes pilihan ganda. Hasil tes uraian disajikan pada Tabel 6.

Tabel 6. Hasil Tes Uraian

\begin{tabular}{ccc}
\hline Tes & Statistika & Peluang \\
\hline Rata-rata & 3,57 & 3,74 \\
Persentase & $82,35 \%$ & $96,77 \%$ \\
\hline
\end{tabular}

Hasil tes uraian menunjukkan bahwa baik untuk materi statistika maupun peluang, ratarata nilai siswa juga lebih dari 2,67 dengan persentase ketuntasan juga lebih dari $75 \%$.

Hasil angket penilaian diri menunjukkan bahwa baik siswa kelas X MIA 5 maupun X MIA 6 telah mencapai kriteria minimal baik dengan rincian disajikan pada Tabel 7.

Tabel 7. Hasil Angket Penilaian Diri

\begin{tabular}{ccc}
\hline Kelas & $\begin{array}{c}\text { Jumlah } \\
\text { Siswa }\end{array}$ & $\begin{array}{c}\text { Persentase Siswa } \\
\text { yang Mencapai KKM }\end{array}$ \\
\hline X MIA 5 & 34 & $97,06 \%$ \\
X MIA 6 & 31 & $87,10 \%$ \\
\hline
\end{tabular}

\section{Pembahasan}

Kurikulum 2013 merupakan kurikulum berbasis kompetensi dan karakter. dalam implementasi Kurikulum 2013, penanaman norma ataupun nilai dapat diintegrasikan dalam setiap bidang studi yang diajarkan. Oleh karena itu, kompetensi inti yang harus dicapai oleh siswa meliputi kompetensi sikap yang terdiri atas kompetensi sikap spiritual (KI-1) dan kompetensi sikap sosial (KI-2), pengetahuan (KI-3), dan keterampilan (KI-4).

Kevalidan Produk

Berdasarkan hasil validasi ahli baik RPP, LKS, THB, dan angket penilaian diri yang kembangkan telah mencapai ktiteria valid. Dengan demikian secara keseluruhan perangkat pembel- ajaran yang dikembangkan dinyatakan valid, sehingga layak digunakan untuk pembelajaran.

\section{Kepraktisan Produk}

Berdasarkan hasil penilaian guru RPP, LKS, dan angket yang dikembangkan telah mencapai kriteria baik. Untuk tes hasil belajar kriteria yang dicapai adalah sangat baik dan secara keseluruhan perangkat pembelajaran yang dikembangkan telah mencapai kategori baik. Dengan demikian, baik secara keseluruhan maupun masing-masing komponen berada pada kategori minimal baik maka dapat dikatakan bahwa perangkat pembelajaran yang dikembangkan praktis untuk digunakan berdasarkan hasil penilaian guru.

Dari hasil penilaian siswa pada uji coba lapangan terhadap LKS diketahui bahwa LKS yang dikembangkan dinyatakan sangat baik. Oleh karena LKS yang digunakan telah memenuhi kategori minimal baik maka LKS tersebut praktis digunakan berdasarkan hasil penilaian siswa. Sementara itu berdasarkan hasil observasi keterlaksanaan pembelajaran diketahui bahwa baik pembelajaran statistika maupun peluang keterlaksanaan masing-masing telah melampaui $80 \%$, sehingga perangkat pembelajaran dapat dikatakan praktis digunakan. Baik dari penilaian guru, penilaian siswa, maupun hasil observasi keterlaksanaan pembelajaran menunjukkan bahwa perangkat pembelajaran praktis digunakan. Dengan demikian secara keseluruhan, perangkat pembelajaran praktis digunakan.

\section{Keefektifan Produk}

Berdasarkan hasil tes pilihan ganda dan uraian diketahui bahwa rata-rata skor siswa pada materi statistika maupun peluang lebih dari kriteria ketuntasan minimal yaitu 2,67. Sementara untuk persentase ketuntasan untuk tes pilihan ganda dan uraian lebih dari $75 \%$ baik untuk materi statistika maupun peluang. Dengan demikian perangkat pembelajaran yang dikembangkan dinyatakan efektif untuk digunakan. Untuk hasil angket penilaian diri, persentase siswa yang mencapai KKM lebih dari $75 \%$ baik untuk kelas X MIA 5 maupun X MIA 6. Hal ini berarti perangkat pembelajaran efektif untuk digunakan berdasarkan hasil angket penilaian diri. Berdasarkan hasil tersebut, dengan demikian secara keseluruhan perangkat pembelajaran yang dikembangkan efektif digunakan.

Hasil penelitian yang diperoleh dari pengembangan perangkat pembelajaran ini menguatkan penelitian terdahulu yang telah dilaku- 
kan peneliti lain seperti penelitian Yuliawati (2010, pp.144-145) yang menyatakan bahwa penerapan pendekatan penemuan terbimbing pada pembelajaran sains dapat meningkatkan karakter dan hasil belajar sains siswa kelas 5 SD Negeri Gembongan, Sentolo, Kulon Progo. Penelitian ini juga menguatkan peneliatian yang dilakukan oleh Akanmu \& Fajemidagba (2013, p.85) bahwa terdapat perbedaan yang signifikan dalam prestasi belajar matematika siswa yang diajar menggunakan strategi pembelajaran penemuan terbimbing dibandingkan dengan siswa yang diajar dengan menggunakan strategi pembelajaran yang lain. Hasil penelitian juga menunjukkan bahwa dengan strategi pembelajaran penemuan terbimbing terjadi peningkatan dalam prestasi belajar siswa. Di samping itu, penelitian ini juga menemukan bahwa perbedaan gender tidak memiliki peran dalam prestasi belajar matematika siswa.

\section{SIMPULAN DAN SARAN}

\section{Simpulan}

Berdasarkan hasil penelitian dan pembahasan diperoleh simpulan bahwa perangkat pembelajaran statistika dan peluang dengan metode penemuan terbimbing yang berorientasi pada Kurikulum 2013 untuk siswa kelas X semester 2 telah memenuhi kriteria valid, praktis dan efektif, sehingga layak untuk digunakan.

\section{Saran}

Beberapa saran pemanfaatan produk antara lain perangkat pembelajaran matematika dengan penemuan terbimbing berorientasi Kurikulum 2013 yang dihasilkan pada penelitian ini telah memenuhi kriteria valid, praktis, dan efektif sehingga layak dimanfaatkan untuk pembelajaran di kelas. Produk perangkat pembelajaran yang dihasilkan dapat dijadikan referensi dan bahan masukan bagi guru dalam menyusun perangkat pembelajaran matematika untuk mengembangkan kompetensi inti siswa yang akan digunakan pada pembelajaran di kelas. Bagi peneliti lain dapat mengembangkan perangkat pembelajaran dengan metode penemuan terbimbing untuk materi dan jenjang pendidikan lainnya.

\section{DAFTAR PUSTAKA}

Afandi, A. (2013). Pendekatan open-ended dan inkuiri terbimbing ditinjau dari kemampuan pemecahan masalah dan representasi multipel matematis. PYTHAGORAS: Jurnal
Pendidikan Matematika, 8(1), 1-11. doi:http://dx.doi.org/10.21831/pg.v8i1.84 89

Akanmu, M. A. \& Fajemidagba, M. O. (2013). Guided-discovery learning strategy and senior school students performance in mathematics in Ejigbo, Nigeria. Journal of Education and Practice, 4(12), 82-89.

Allen, M. J. \& Yen, W. M. (1979).Introduction to measurement theory. Belmont, $\mathrm{CA}$ : Wadsworth, Inc.

Alfieri, L., et al. (2011). Does discovery-based instruction enhance learning?. Journal of Educational Psychology, 103(1), 1-18.

Anderson, L. W. \& Krathwohl. (2001). A taxonomy for learning, teaching, and assessing. New York, NY: Addison Wesley Longman Inc.

Azwar, S. (2015). Tes prestasi: fungsi dan pengembangan pengukuran prestasi belajar (edisi ke-2). Yogyakarta: Pustaka Pelajar.

Bell, F. H. (1981). Teaching and learning mathematics (in secondary school). Dubuque, IA: Wm. C. Brown Company.

Boynton, M. \& Boynton, C. (2005). The educator's guide to preventing and solving discipline problems, Alexandria, VA: ASCD.

Holdcroft, B. (2006). What is religiosity?. Catholic Education: A Journal of Inquiry and Practice, 10(1), 89-103.

Hurlock, E. B. (1996). Psikologi Perkembangan (Edisi kelima). (Terjemahan Istiwidayanti \& Soedjarwo). Jakarta: Erlangga

Kirschner, P. A., Sweller, J., \& Clark, R. E. (2006). Why minimal guidance during instruction does not work: an analysis of the failure of constructivist, discovery, problem-based, experiential, and inqurybased teaching. Educational Psychologist. 41(2), 75-86.

Koellhoffer, T. T. (2009). Character education: being fair and honest. New York, NY: Infobase Publishing.

Kurniawan, D., \& Wustqa, D. (2014). Pengaruh perhatian orangtua, motivasi belajar, dan lingkungan sosial terhadap prestasi belajar matematika siswa SMP. Jurnal Riset 
Pendidikan Matematika, 1(2), 176-187. doi:http://dx.doi.org/10.21831/jrpm.v1i2. 2674

Lickona, T. (2004). Character matters: how to help our children develop good judgment, integrity, and other essential virtues. New York, NY. Touchstone.

Lickona, T. (1991). Educating for character: how our schools can teach respect and responsibility. New York, NY: Bantam Books.

Mayer, R. E. (2004). Should there be athreestrikes rule against pure discovery learning?. American Psychologist, 59(1), 14-19.

Menlove, F. L. (2012). The challenge of honesty. Dialogue: A Journal of Mormon Thought, 1(1), 44-53.

Miller, M. D., Linn, R. L., \& Gronlund, N. E. (2009). Measuremet and assessment in teaching $\left(10^{\text {th }} \mathrm{Ed}\right.$.) Upper Saddle River, NJ: Pearson Education, Inc.

Mendikbud. (2014a). Peraturan Menteri Pendidikan dan Kebudayaan Republik Indonesia Nomor 59 Tahun 2014, tentang Kurikulum 2013 Sekolah Menengah Atas/Madrasah Aliyah.

Mendikbud. (2014b). Peraturan Menteri Pendidikan dan Kebudayaan Republik Indonesia Nomor 103 Tahun 2014, tentang Pembelajaran pada Pendidikan Dasar dan Pendidikan Menengah.

Mendikbud. (2014c). Peraturan Menteri Pendidikan dan Kebudayaan Republik Indonesia Nomor 104 Tahun 2014, tentang Penilaian Hasil Belajar oleh Pendidik pada Pendidikan Dasar dan Pendidikan Menengah.

Moore, K. D. (2009). Effective instructional strategies: from theory to practice $\left(2^{\text {nd }}\right.$ Ed.). Thousand Oaks, CA: Sage Publications.

NCTM. (2000). Principles and standards for school mathematics. Reston, VA: NCTM Inc.

Nitko, A. J. \& Brookhart, S. M. (2011). Educational assessment of students $\left(6^{\text {th }}\right.$ $E d$.). Boston, MA: Pearson Education, Inc.
Orton, A. (2006). Learning mathematics (3 $3^{\text {rd }}$ $E d$.). London: Continuum.

Rumasoreng, M., \& Sugiman, S. (2014). Analisis kesulitan matematika siswa SMA/MA dalam menyelesaikan soal setara UN di Kabupaten Maluku Tengah. Jurnal Riset Pendidikan Matematika, l(1), 22-34. doi:http://dx.doi.org/10.21831/jrpm.v1i1. 2661

Salleh, M.S. (2012). Religiosity in development: atheoretical construct of an Islamic-based development. International Journal of Humanities And Social Science. , 2(14), 266-274.

Schunk, D. H. (2008). Learning theories: an educational perspective ( $5^{\text {th }} \mathrm{Ed}$.), Upper Saddle River, NJ: Pearson Education, Inc.

Smith, P. L. \& Ragan, T. J. (2005). Instructional design ( $3^{\text {rd }} E d$.). Hoboken, NJ: John Wiley \& Sons, Inc.

Stringer, E. T., Christensen, L. M, \& Baldwin, S. C. (2010). Integrating teaching, learning and action research. Thousand Oaks, CA: SAGE Publication Inc.

Suydam, M. N. \& Dessart, D. J. (1980). Skill learning. Dalam R. Shumway. (1980). Research Mathematics Education. Ohio State University: National Council Teachers of Mathematics.

Syawahid, M., \& Retnawati, H. (2014). Pengembangan perangkat pembelajaran matematika terintegrasi dengan pengembangan kecerdasan emosional dan spiritual. Jurnal Riset Pendidikan Matematika, $\quad 1(1), \quad 12-21$. doi:http://dx.doi.org/10.21831/jrpm.v1i1. 2654

Tamayo, A. M. (2014). Virtues of honesty in a higher education institution. American Journal of Social Sciences, 2(1), 1-6.

Thiagarajan, S., Semmel D. S., \& Semmel, M. I. (1974). Instructional development for training teachers of exceptional children. Minneapolis, MN: University of Minnesota

Tiliouine, H. \& Belgoumidi, A. (2009). An exploratory study of religiosity, meaning in life and subjective wellbeinng in 
muslim students from Algeria. Applied Research Quality Life, 4(1), 109-127.

Tran, T., et al. (2014). Discovery learning with the help of geogebra dynamic geometry software. International Journal of Learning, Teaching and Educational Research, 7(1), 44-57.
Yuliawati, F. (2010). Penerapan pendekatan penemuan terbimbing untuk meningkatkan karakter dan hasil belajar siswa kelas 5 SD Negeri Gembongan Sentolo Kulon Progo. Tesis magister, tidak diterbitkan, Universitas Negeri Yogyakarta. 